\title{
Genomic Analysis and Secondary Metabolites Production of the Endophytic Bacillus velezensis Bvel1: A Biocontrol Agent against Botrytis cinerea Causing Bunch Rot in Post-Harvest Table Grapes
}

\author{
Kallimachos Nifakos ${ }^{1,2}$, Polina C. Tsalgatidou ${ }^{1}$ (D), Eirini-Evangelia Thomloudi ${ }^{1} \mathbb{D}$, Aggeliki Skagia $^{1}$, \\ Dimitrios Kotopoulis ${ }^{1}$ (D), Eirini Baira ${ }^{3}$ (D) Costas Delis ${ }^{2}$ (D), Konstantinos Papadimitriou ${ }^{4}$, Emilia Markellou ${ }^{5}$, \\ Anastasia Venieraki ${ }^{6, *}$ and Panagiotis Katinakis ${ }^{1, *}$
}

check for updates

Citation: Nifakos, K.; Tsalgatidou, P.C.; Thomloudi, E.-E.; Skagia, A.; Kotopoulis, D.; Baira, E.; Delis, C.; Papadimitriou, K.; Markellou, E.; Venieraki, A.; et al. Genomic Analysis and Secondary Metabolites Production of the Endophytic Bacillus velezensis Bvel1: A Biocontrol Agent against Botrytis cinerea Causing Bunch Rot in Post-Harvest Table Grapes. Plants 2021, 10, 1716. https:/ / doi.org/10.3390/plants10081716

Academic Editor: Jane Debode

Received: 1 August 2021

Accepted: 17 August 2021

Published: 20 August 2021

Publisher's Note: MDPI stays neutral with regard to jurisdictional claims in published maps and institutional affiliations.

Copyright: (C) 2021 by the authors Licensee MDPI, Basel, Switzerland. This article is an open access article distributed under the terms and conditions of the Creative Commons Attribution (CC BY) license (https:// creativecommons.org/licenses/by/ $4.0 /)$.
1 Laboratory of General and Agricultural Microbiology, Crop Science Department, Agricultural University of Athens, Iera Odos 75, 11855 Athens, Greece; k.nifakos@go.uop.gr (K.N.); polinatsal@gmail.com (P.C.T.); e.e.thomloudi@gmail.com (E.-E.T.); Angeliki.Skagia@warwick.ac.uk (A.S.); drkotopoulis@gmail.com (D.K.)

2 Department of Agriculture, University of the Peloponnese, 24100 Kalamata, Greece; delis@us.uop.gr

3 Laboratory of Toxicological Control of Pesticides, Scientific Directorate of Pesticides' Control and Phytopharmacy, Benaki Phytopathological Institute (BPI), 8 St. Delta Street, Kifissia, 14561 Athens, Greece; e.baira@bpi.gr

4 Department of Food Science and Technology, University of the Peloponnese, 24100 Kalamata, Greece; kostas.papadimitriou@gmail.com

5 Scientific Directorate of Phytopathology, Benaki Phytopathological Institute (BPI), 14561 Athens, Greece; e.markellou@bpi.gr

6 Laboratory of Plant Pathology, Crop Science Department, Agricultural University of Athens, Iera Odos 75, 11855 Athens, Greece

* Correspondence: venieraki@aua.gr (A.V.); katp@aua.gr (P.K.)

Abstract: Botrytis bunch rot caused by Botrytis cinerea is one of the most economically significant postharvest diseases of grapes. In the present study, we showed that the bacterial strain Bvel1 is phylogenetically affiliated to Bacillus velezensis species. The strain Bvel1 and its secreted metabolites exerted an antifungal activity, under in vitro conditions, against B. cinerea. UHPLC-HRMS chemical analysis revealed that iturin $\mathrm{A} 2$, surfactin-C13 and -C15, oxydifficidin, bacillibactin, L-dihydroanticapsin, and azelaic acid were among the metabolites secreted by Bvel1. Treatment of wounded grape berries with Bacillus sp. Bvel1 cell culture was effective for controlling grey mold ingress and expansion in vivo. The effectiveness of this biological control agent was a function of the cell culture concentration of the antagonist applied, while preventive treatment proved to be more effective compared to curative. The strain Bvel1 exhibited an adequate colonization efficiency in wounded grapes. The whole-genome phylogeny, combined with ANI and dDDH analyses, provided compelling evidence that the strain Bvel1 should be taxonomically classified as Bacillus velezensis. Genome mining approaches showed that the strain Bvel1 harbors 13 antimicrobial biosynthetic gene clusters, including iturin A, fengycin, surfactin, bacilysin, difficidin, bacillaene, and bacillibactin. The results provide new insights into the understanding of the endophytic Bacillus velezensis Bvel1 biocontrol mechanism against post-harvest fungal pathogens, including bunch rot disease in grape berries.

Keywords: endophytic bacteria; metabolites; iturin A; surfactin; genome sequence; colonization; biological control; induced systemic resistance

\section{Introduction}

Botrytis bunch rot (grey mold) caused by the necrotrophic fungal pathogen Botrytis cinerea is a major disease of grapevines. Infection of ripening berries leads to large losses in the quantity and quality of both table and wine grapes, either in the field or under post-harvest storage conditions [1]. 
Although grey mold control has been mainly achieved using synthetic fungicides, public concerns regarding their adverse effects on the environment and human health have prompted the search for alternative disease control methodologies [1]. Among several scientific approaches, a promising alternative for grey mold management is the use of microorganisms (e.g., Trichoderma spp., Bacillus spp., Candida spp., and Aureobasidium pullulans) as biological control agents (BCAs) [2-4].

In recent years, bacterial strains of the genus Bacillus have received great attention as biocontrol agents against post-harvest fungal pathogens that infect fruits and vegetables [5] Various mechanisms have been implicated in the Bacillus spp. protective effect, which include competition for space and nutrients, antibiosis through the secretion of compounds exhibiting antimicrobial activities, secretion of enzymes that degrade the plant pathogen cell wall, and induction of host resistance [6].

Numerous studies on the plant protection mechanisms of microbial biocontrol agents have demonstrated that the biological control effect of Bacillus sp. species is associated with their capacity to produce a plethora of bioactive molecules, with the lipopeptides (LPs) being the most well studied [5]. Bacillus sp. biosynthesized lipopeptides can be generally classified into various families based on the peptide amino acid composition and the fatty acid chain length; with fengycins, surfactins, and iturins being the three best known families [7]. Bacillus sp. mutants defective in lipopeptide biosynthesis, as well as cell-free culture supernatant (CFCS) from these mutants' strains, lost their activity to suppress post-harvest pathogenic fungi, suggesting that the secreted lipopeptides are involved in the biocontrol activity of these antagonistic Bacillus strains [8-11]. Furthermore, it has been demonstrated that lipopeptides such as iturin, bacillomycin, and fengycin, besides their strong and broad-spectrum antifungal and/or antibacterial activity [12], may also serve as elicitors of plant-induced systemic resistance [13-17].

Recent studies, have demonstrated that endophytic Bacillus sp. may be considered as effective BCA candidates counteracting post-harvest disease in fruit and vegetables [18]. Endophytic antagonistic Bacillus species have the ability to colonize plant interior tissues without causing any visible symptoms of disease to their plant hosts, while in most cases they contribute to the promotion of plant growth and protection against both biotic and abiotic stress factors [6]. Endophytic Bacillus may also be more likely to succeed as biocontrol agents as a result of their environmental adaptation to host plant metabolites and their ability to occupy ecological niches similar to fungal pathogens, such as B. cinerea, that exhibit a latent or necrotrophic behavior [18]. Recent studies exploring the biocontrol capacity of endophytic Bacillus strains against post-harvest pathogens have demonstrated the successfully suppression of the proliferation of Fusarium dry rot in potato [19], B. cinerea in tomato [20], and Colletotrichum acutatum in banana [21].

In the present study, we aimed to gain an insight into the biocontrol potential of the endophytic bacterial strain Bvel1, by (1) investigating the taxonomic position of the bacterial strain Bvel1, (2) examining the antifungal potential of the strain Bvel1 and its secreted metabolites against $B$. cinerea in vitro, (3) identifying the antifungal compounds present in the secreted metabolites using analytical chemistry, (4) assessing the in vivo efficacy of strain Bvel1 cell cultures to control grey mold ingress and expansion in harvested table grapes, and (5) gaining an insight into the biosynthetic gene clusters involved in the synthesis of antimicrobial secondary metabolites.

\section{Results}

\subsection{Taxonomic Classification of the Bacterial Stain Bvel1}

Among the 36 endophytic bacterial strains isolated from olive tree roots, the strain Bvel1 showed the highest antagonistic activity against the post-harvest fungal pathogen $B$. cinerea and, therefore, was selected for further studies.

BlastN analysis based on 16S rRNA gene sequences against the public available database of NCBI (National Center for Biotechnology Information, https:/ / www.ncbi. nlm.nih.gov (accessed on 15 June 2021) indicated that the strain Bvel1 is closely related 
(>99.00\% identity) to strains of B. velezensis and B. amyloliquefaciens. For accurate taxonomic assignment of the Bacillus strain Bvel1 we compared the strain Bvel1 at a genomic level with strains belonging to the B. amyloliquefaciens group [22] and the type strains of the closely related Bacillus species deposited in the Type Strain Genome Server (TYGS) bioinformatics platform (https:/ / tygs.dsmz.de (accessed on 13 August 2021)) [23]. As shown in Figure 1, Bvel1 was grouped into B. velezensis species.

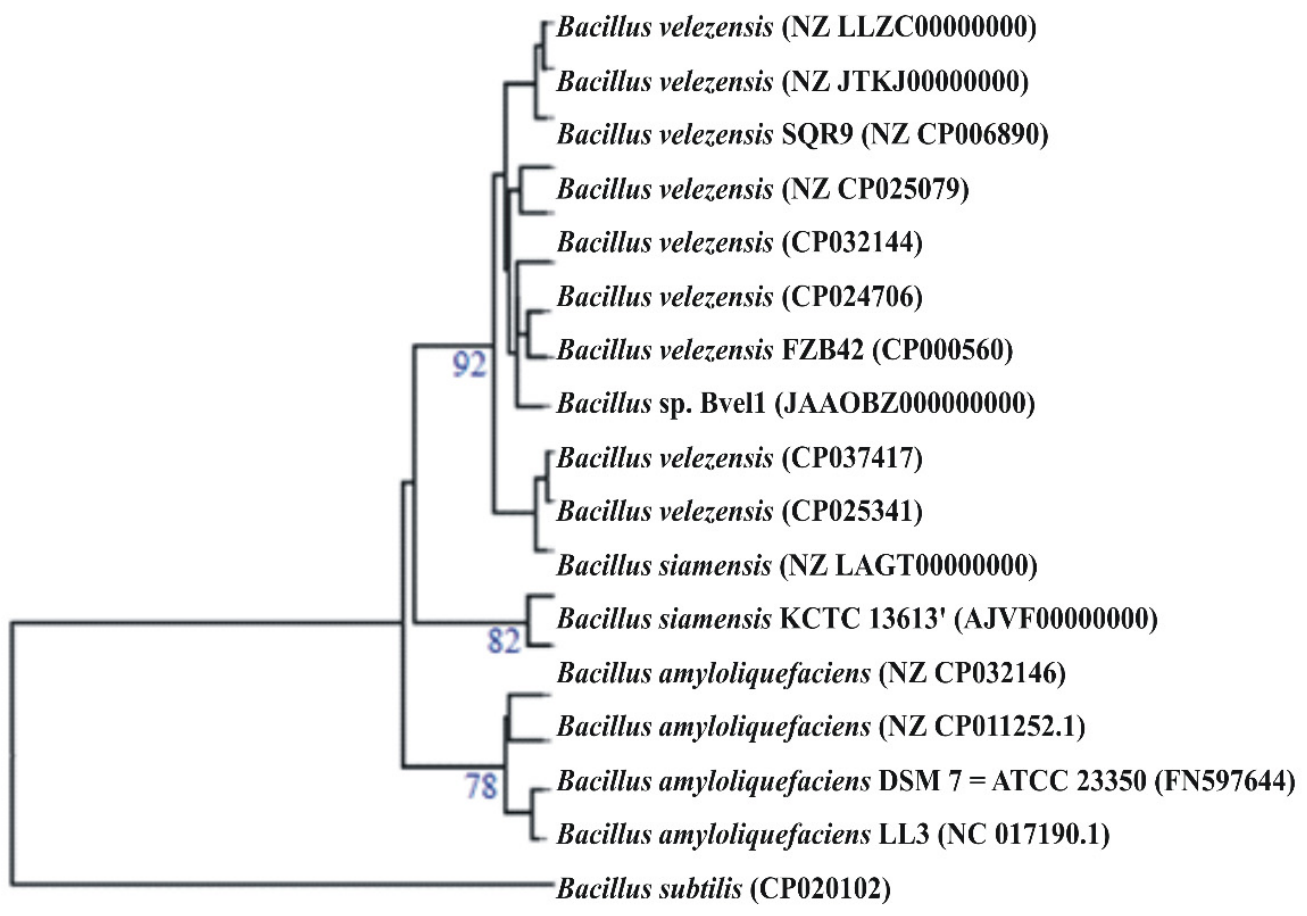

Figure 1. Whole-genome-based phylogenetic tree highlighting the position of Bacillus Bvel1 relative to other closely related Bacillus species. Tree inferred with FastME 2.1.6.1 [24] from genome-blast distance phylogeny (GBDP) distances calculated from genome sequences. The branch lengths are scaled in terms of GBDP distance formula d5. The numbers above the branches are GBDP pseudo-bootstrap support values > 75\% from 100 replications, with an average branch support of $84 \%$. The tree was rooted at the midpoint [24,25]. Leaf labels with different colors indicate species and subspecies clusters.

Average nucleotide identity (ANI) and digital DNA-DNA hybridization (dDDH) analyses showed that the strain Bvel1 is phylogenetically related to members of $B$. velezensis species (Table 1). The similarity of $97.75 \%$ of $\mathrm{dDDH}$ and $79.50 \%$ of ANI values between strain Bvel1 and B. velezensis NRRL B-41580 confirmed that Bvel1 was affiliated to B. velezensis species (Table 1). The highest ANI and $\mathrm{dDDH}$ values were observed for $B$. velezensis LB002. 
Table 1. ANI and dDDH values obtained from the comparison of strain Bvel1 with bacterial strains closely related to the B. amyloliquefaciens and B. velezensis groups.

\begin{tabular}{|c|c|c|}
\hline Bacterial Strains & OrthoANI (\%) & dDDH (\%) \\
\hline Bacillus velezensis Bvel1 & 100.00 & 100.00 \\
\hline B. amyloliquefaciens DSM $7^{\mathrm{T}}$ & 93.94 & 55.10 \\
\hline B. amyloliquefaciens LL3 & 93.86 & 54.50 \\
\hline B. amyloliquefaciens YP6 & 94.03 & 55.10 \\
\hline B. velezensis $\mathrm{Y} 2$ & 97.70 & 80.00 \\
\hline B. velezensis FZB42 & 97.70 & 80.10 \\
\hline B. velezensis QST713 & 97.62 & 79.20 \\
\hline B. velezensis Lzh-a42 & 97.82 & 80.00 \\
\hline B. velezensis LB002 & 98.70 & 99.84 \\
\hline B. velezensis SQR9 & 97.70 & 79.40 \\
\hline B. velezensis NRRL B- $41580^{\mathrm{T}}$ & 97.75 & 79.50 \\
\hline
\end{tabular}

$\mathrm{T}$ type strain.

The whole genome sequences of strains Bvel1 and LB002 were compared using progressive MAUVE (Figure S1, Supplementary Materials). The currently available plasmid Bvel1 sequence exhibited a high identity with an unnamed plasmid of Bacillus velezensis 10075 (Figure S1, Supplementary Materials). Metabolic features of the strain Bvel1 were investigated using KEGG, COG, and CAZy. A significant proportion of the proteins could be assigned to the different categories of KEGG and COG supporting housekeeping and non-housekeeping functions (Figures S2 and S3, Supplementary Materials). It is worth noting that a significant percentage of the predicted proteins were of unknown function.

2.2. In Vitro Antagonistic Activity of Bacillus velezensis Bvel1 and Its Secreted Metabolites against B. cinerea

The disease suppressive potential of Bvel1 was assessed as its growth inhibitory activity against a $B$. cinerea strain, using a dual-culture assay. In all repetitions of the experiment, a clear zone of $>0.7 \mathrm{~cm}$ was formed between the fungus and the Bacillus inoculum suppressing fungal mycelia radial growth by $70 \%$ compared to the control (Figure 1A). The width of the clear zone remained unaffected for at least 5 days.

The agar diffusible compounds secreted by Bvel1 when grown individually or during interactions with $B$. cinerea, referred to as ESC1 and ESC2, respectively, were also evaluated for their antifungal activity using a well-diffusion confrontation assay and a TLCbioautography method. The results suggested that the antifungal metabolites present in both ESCs were diffused into the agar and retained their antifungal activity for at least 5 days (suppressing expansion and growth of the fungal colony) (Figure 2B). The antifungal metabolites present in both ESCs were further characterized by TLC-bioautography using B. cinerea as an indicator (Figure 2C). Data revealed that both ECSs formed a strong inhibition zone suppressing conidial germination with an identical Rf value (0.55) (Figure 2C), suggesting that similar antifungal metabolites are produced and secreted by the strain Bvel1, either constitutively or during confrontation with B. cinerea. 

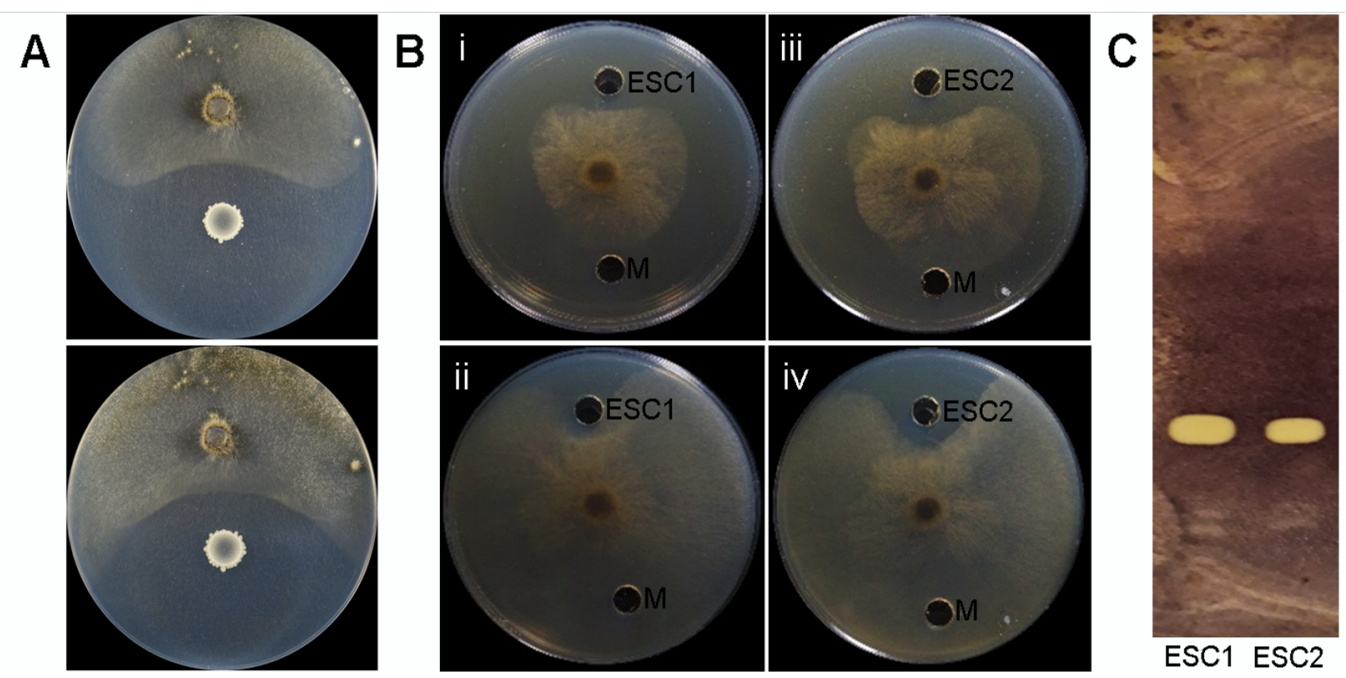

Figure 2. Antifungal activity of Bvel1 culture and its extracted secreted compounds (ESC) against B. cinerea. ESC1 and ESC2 represent extracted secreted compounds of Bvel1 when grown singly and paired with B. cinerea, respectively. (A) Direct antifungal activity of Bacillus velezensis Bvel1 using a dual culture assay at $3 \mathrm{~d}$ (top) and $5 \mathrm{~d}$ (bottom) of the interaction. (B) Antifungal activity of ESC1, ESC2, and M (methanol) using a well-diffusion confrontation assay at 3 days (i, iii) and 5 days of interaction (ii, iv). (C) TLC- bioautography using ESC1 and ESC2.

\subsection{UHPLC-HRMS Analysis of Secreted Metabolites Produced by Strain Bvel1}

Ultra-high-performance liquid chromatography coupled to Q Exactive Orbitrap highresolution mass spectrometry (UHPLC-HRMS) was employed for the identification of the secondary metabolites produced by the strain Bvel1. UHPLC-HRMS chemical analysis of ESC1 revealed the presence of lipopeptides such as iturin and surfactin (Table 2).

Table 2. UHPLC-HRMS analysis of the secondary metabolites secreted by Bvel1.

\begin{tabular}{|c|c|c|c|c|c|c|}
\hline $\begin{array}{l}\text { Antibiotic } \\
\text { Compounds }\end{array}$ & $\begin{array}{l}\text { Molecular } \\
\text { Formula }\end{array}$ & $\begin{array}{c}\text { Experimental } \\
\mathrm{m} / \mathrm{z}\end{array}$ & $\begin{array}{c}\text { RT } \\
\text { (min) }\end{array}$ & $\Delta \mathrm{m}(\mathrm{ppm})$ & Adduct & References \\
\hline Surfactin A-C13 & $\mathrm{C}_{51} \mathrm{H}_{89} \mathrm{~N}_{7} \mathrm{O}_{13}$ & 1006.6457 & 22,699 & 2.22 & {$[\mathrm{M}-\mathrm{H}]^{-}$} & [26] \\
\hline Surfactin A-C15 & $\mathrm{C}_{53} \mathrm{H}_{93} \mathrm{~N}_{7} \mathrm{O}_{13}$ & 1034.6762 & 23,945 & 1.39 & {$[\mathrm{M}-\mathrm{H}]^{-}$} & [27] \\
\hline Iturin A2-C14 & $\mathrm{C}_{48} \mathrm{H}_{74} \mathrm{~N}_{12} \mathrm{O}_{14}$ & 1041.5351 & 14,310 & -1.22 & {$[\mathrm{M}-\mathrm{H}]^{-}$} & [28] \\
\hline L-dihydroanticapsin & $\mathrm{C}_{9} \mathrm{H}_{15} \mathrm{NO}_{4}$ & 200.0923 & 11,395 & 2.83 & {$[\mathrm{M}-\mathrm{H}]^{-}$} & [29] \\
\hline Oxydifficidin & $\mathrm{C}_{31} \mathrm{H}_{45} \mathrm{O}_{7} \mathrm{P}$ & 559.2836 & 16,950 & 3.01 & {$[\mathrm{M}-\mathrm{H}]^{-}$} & [30] \\
\hline Bacillibactin & $\mathrm{C}_{39} \mathrm{H}_{42} \mathrm{~N}_{6} \mathrm{O}_{18}$ & 881.2497 & 11,880 & 2.85 & {$[\mathrm{M}-\mathrm{H}]^{-}$} & [31] \\
\hline Azelaic acid & $\mathrm{C}_{9} \mathrm{H}_{16} \mathrm{O}_{4}$ & 187.0969 & 11,012 & 2.22 & {$[\mathrm{M}-\mathrm{H}]^{-}$} & [32] \\
\hline
\end{tabular}

The annotation of the compounds was based on the accurate mass ( $\pm 5 \mathrm{ppm})$, as well as the isotope distribution. The accurate masses obtained from ions $m / z 1041.5351[\mathrm{M}-\mathrm{H}]^{-}$ and $m / z 1087.5434[\mathrm{M}+\mathrm{FA}-\mathrm{H}]^{-}$(adduct with formic acid) revealed the presence of a compound with the molecular formula $\mathrm{C}_{48} \mathrm{H}_{74} \mathrm{~N}_{12} \mathrm{O}_{14}$, indicating the presence of iturin A2 (Figure 3C). In addition, HRMS analysis revealed the presence of compounds with the elemental composition of $\mathrm{C}_{51} \mathrm{H}_{89} \mathrm{~N}_{7} \mathrm{O}_{13}$ and $\mathrm{C}_{53} \mathrm{H}_{93} \mathrm{~N}_{7} \mathrm{O}_{13}$, and ions with $\mathrm{m} / z 1006.6457$ $[\mathrm{M}-\mathrm{H}]^{-}$and $m / z 1034.6762[\mathrm{M}-\mathrm{H}]^{-}$, indicating the presence of surfactin A-C13 and surfactin A-C15, respectively (Figure 3A,B). The compounds with $m / z$ 881.2488 [M - H] ${ }^{-}$ and $m / z 559.2836[\mathrm{M}-\mathrm{H}]^{-}$were attributed to the siderophore bacillibactin and the antibacterial polyketide oxydifficidin, respectively. The compound with $m / z 200.0923[\mathrm{M}-\mathrm{H}]^{-}$ was assigned to the antibacterial and antifungal component of L-dihydroanticapsin [33]. Ion signals at a $m / z$ value of 187.0969 were assigned to azelaic acid (Figure 3G). 

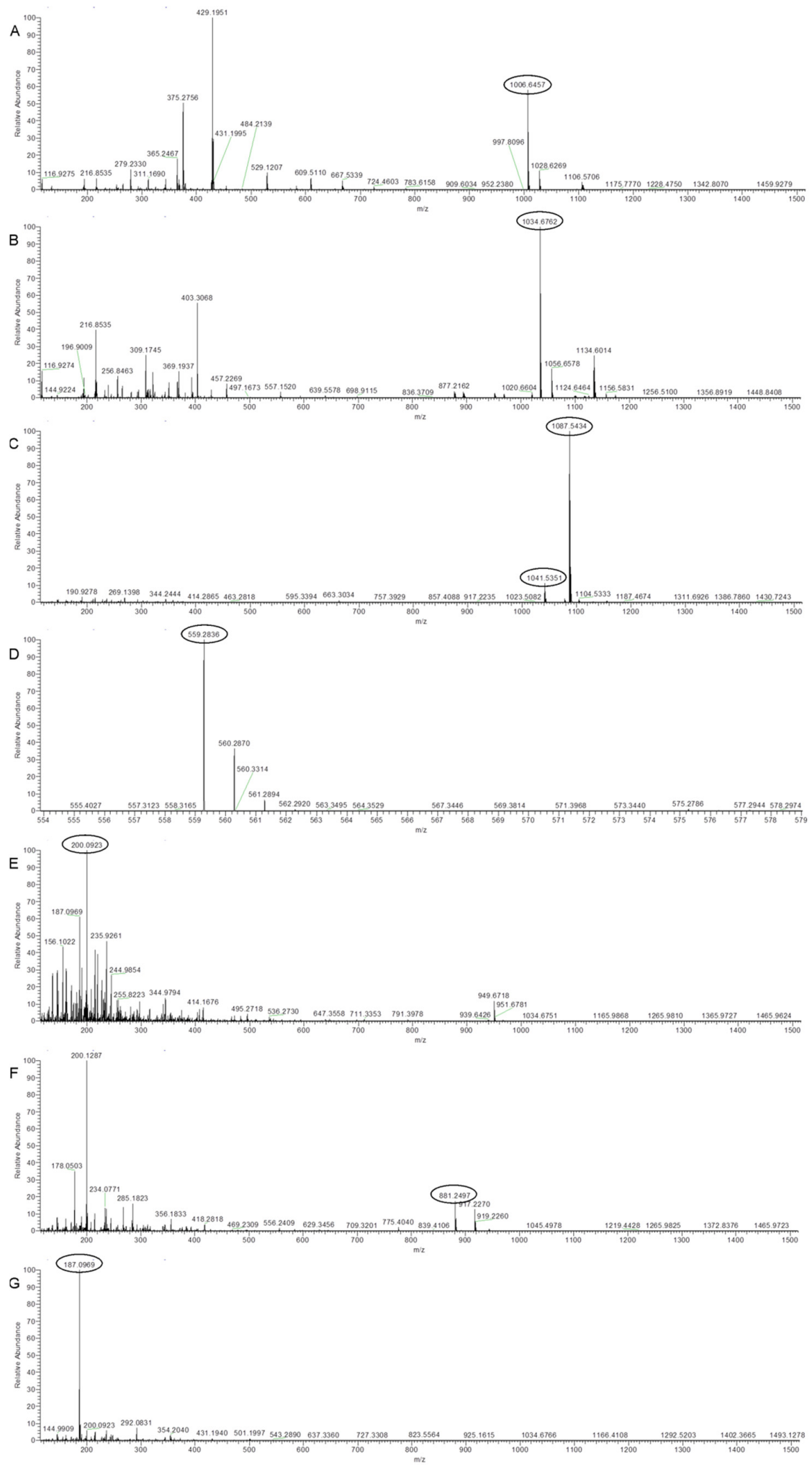

Figure 3. Spectra from Orbitrap high-resolution mass spectrometry (UHPLC-HRMS) analysis of the compounds secreted by Bvel1. (A) Surfactin A -C13, (B) Surfactin A -C15, (C) Iturin A2 -C14, (D) Oxydifficidin, (E) L-dihydroanticapsin, (F) Bacillibactin, and (G) Azelaic acid. The $m / z$ of the compounds mentioned are circled on the spectra. 


\subsection{Preventive and Curative Action of Strain Bvel1 against B. cinerea on Grape Berries}

To test the in planta antagonistic activity of strain Bvel1 against $B$. cinerea, we tested the inhibitory effect of a high $\left(10^{8} \mathrm{CFU} / \mathrm{mL}\right)$ and medium $\left(10^{6} \mathrm{CFU} / \mathrm{mL}\right)$ bacterial density culture of Bvel1 against B. cinerea on wounded berries either prior (preventive treatment) or after (curative treatment) artificial inoculation with a conidial suspension of $B$. cinerea. The preventive treatment showed greater effectiveness than the curative treatment, and the disease severity (\% berry area covered by lesions) of the berries was reduced during the incubation period. Treatment with Bvel1 cell culture prior to B. cinerea inoculation strongly suppressed fungal growth and significantly reduced the incidence of grey mold (\% of berries showing rot symptoms) on red globe grapes, 3 days after artificial inoculation, in a cell density dependent manner (Figures 4 and 5). Disease incidence of grape berries treated with Bvel1 at different concentrations was reduced to $25.33 \%\left(1 \times 10^{6} \mathrm{CFU} / \mathrm{mL}\right)$ and $16.33 \%\left(1 \times 10^{8} \mathrm{CFU} / \mathrm{mL}\right)$, in comparison to $81.10 \%$ for the control (water) treatment. Furthermore, treatment with Bvel1 cells culture $24 \mathrm{~h}$ prior to inoculation also reduced disease severity values after 3 or 6 days of artificial inoculation, in a cell concentration dependent manner. As depicted in Figure 4, the disease severity of grey mold on the infected grape berries decreased to $14.33 \%$ and $82.57 \%\left(1 \times 10^{6} \mathrm{CFU} / \mathrm{mL}\right)$ and to $10.33 \%$ and $70.33 \%\left(1 \times 10^{8} \mathrm{CFU} / \mathrm{mL}\right)$ after 3 and 6 days of artificial inoculation, respectively, in comparison to $56.33 \%$ and $96.33 \%$ for the control treatment (Figure 4 ).

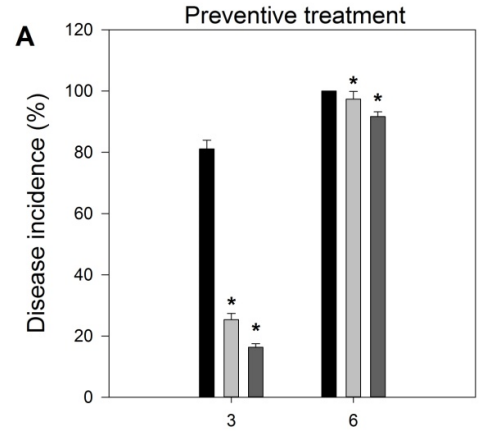

Days after artificial inoculation (DAAI)

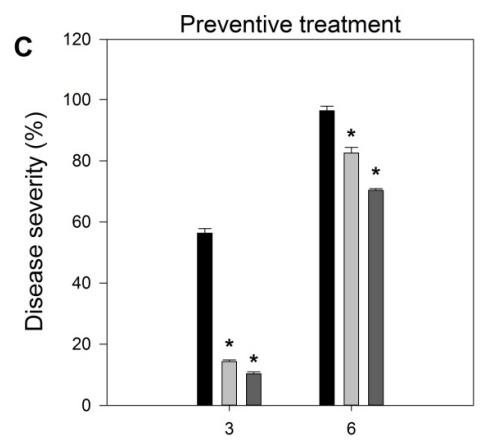

Days after artificial inoculation (DAAI)

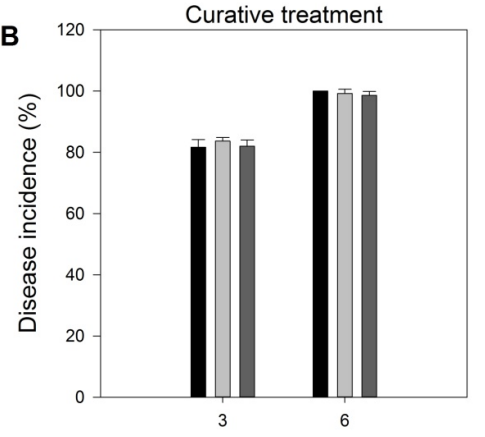

Days after artificial inoculation (DAAI)

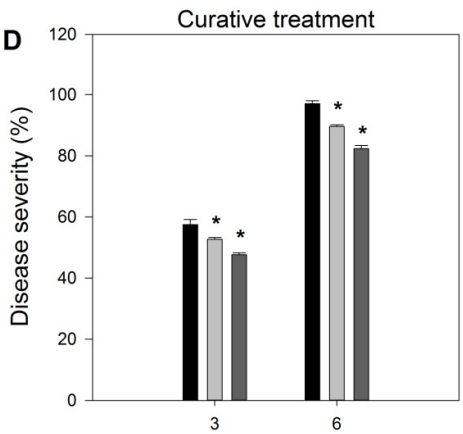

Days after artificial inoculation (DAAI)

$$
\left.\square \text { B. cinerea } \square \text { Bvel1 (10 } 0^{6} \mathrm{CFU} / \mathrm{ml}\right) \square \text { Bvel1 }\left(10^{8} \mathrm{CFU} / \mathrm{ml}\right)
$$

Figure 4. The effect of preventive and curative treatment with different concentrations $\left(10^{6}\right.$ and $10^{8} \mathrm{CFU} / \mathrm{mL}$ ) of endophytic bacterial strain Bvel1 against grey mold on berries. (A) Disease incidence (\% infected berries) of the preventive bacterial treatment, (B) disease incidence (\%) of the curative bacterial treatment, $(\mathbf{C})$ disease severity (\% berry area with lesions) of the preventive bacterial treatment, (D) disease severity (\%) of the curative bacterial treatment. Data values represent the mean of 3 biological replicates \pm SD after $t$-test analysis. Asterisks indicate statistically significant differences of each treatment when compared to the control (B. cinerea) at each incubation timepoint $(p<0.05)$. 


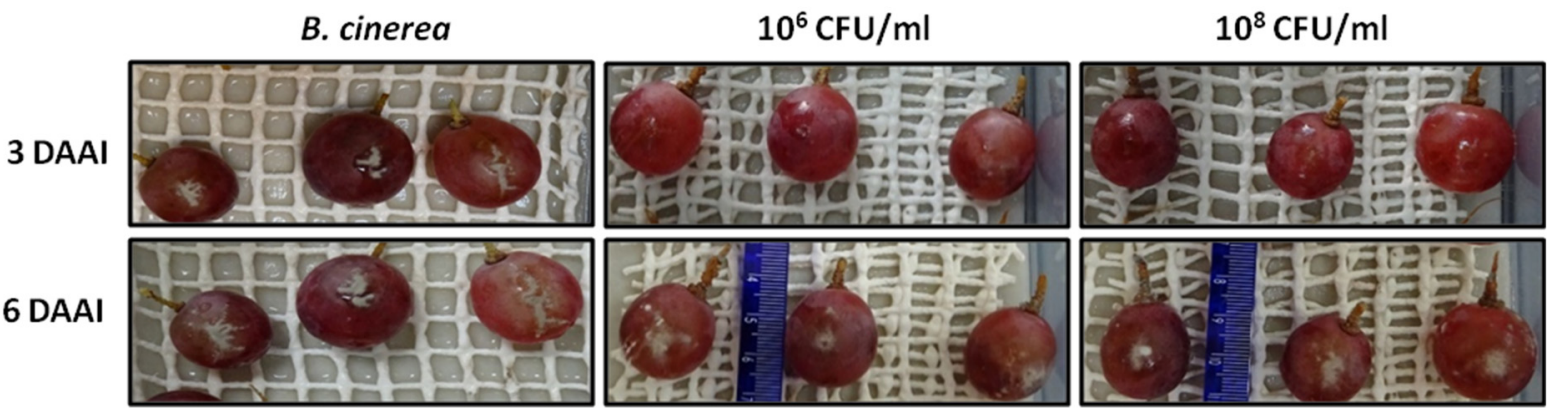

Figure 5. Biocontrol activity of antagonistic Bvel1 against B. cinerea on wounded red globe grapes. Wounded grapes treated with different concentrations $\left(10^{6}\right.$ and $\left.10^{8} \mathrm{CFU} / \mathrm{mL}\right)$ of the endophytic bacterial strain Bvel1, 1 day prior to artificial inoculation with B. cinerea. Pictures were taken 3 days and 6 days after artificial inoculation (DAAI) and incubation at $25^{\circ} \mathrm{C}$.

\subsection{Bacillus velezensis Bvel1 Colonization in Wounded Berries}

In the preventive treatment, the strain Bvel1 successfully colonized wounds both in the presence and absence of $B$. cinerea during the incubation period at $22{ }^{\circ} \mathrm{C}$ (Figure 6). The number of Bacillus-type colonies within the inoculated fruits increased rapidly from $1.09 \log 10 \mathrm{CFU} /$ wound to $2.91 \log 10 \mathrm{CFU} /$ wound in the presence of the fungus, and from $1.12 \log 10 \mathrm{CFU} /$ grape to $2.87 \log 10 \mathrm{CFU} /$ wound in the absence of the fungus, after 3 days of artificial inoculation. Bvel1 reached its maximum population after 4 days of artificial inoculation either in the presence or the absence of $B$. cinerea (3.50 log $10 \mathrm{CFU} /$ grape and $3.44 \log 10 \mathrm{CFU} /$ wound, respectively), while after 5 days of artificial inoculation its population decreased slightly to $3.13 \log 10 \mathrm{CFU} /$ wound and $3.07 \log 10 \mathrm{CFU} /$ wound, respectively (Figure 6).

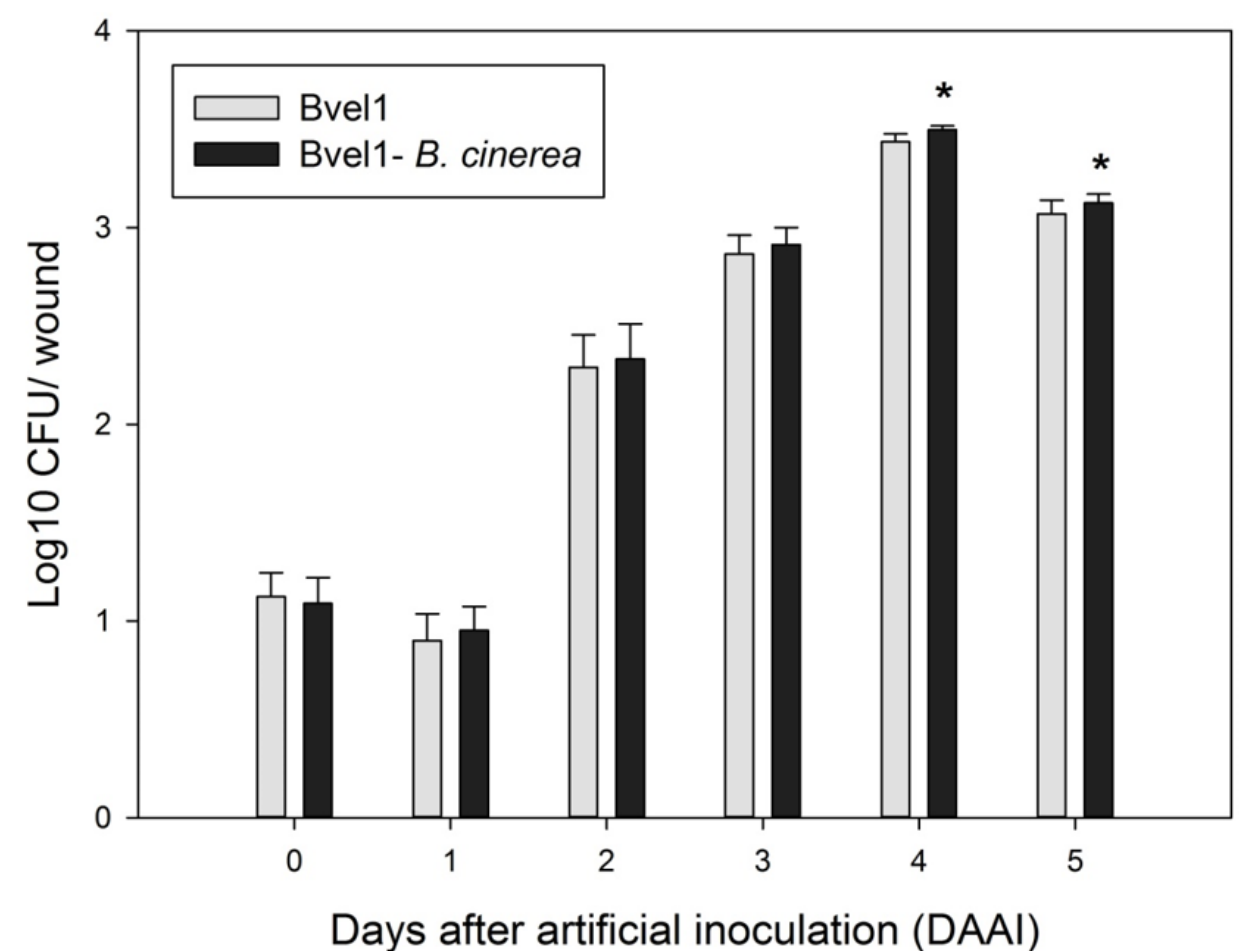

Figure 6. Time growth curve of Bvel1 (Log10 CFU/wound) in grape wounds (one wound in each grape) with and without the presence of the fungus $B$. cinerea. Data values represent the mean of 3 biological replicates $\pm \mathrm{SD}$ after $t$-test analysis. Asterisks indicate the statistical difference between the two treatments $(p<0.05)$. 


\subsection{Genomic Insights into the Antifungal Activity of the Strain Bvel1}

The genome of Bvel1 was analyzed for the presence of secondary metabolite biosynthetic gene clusters (BGCs) using antiSMASH. AntiSMASH predicted 13 putative BGCs of secondary metabolites for the strain Bvel1 genome, covering 20.4\% (805.7 kb) of the whole genome (Table 3). The majority of BGCs could be assigned to known compounds, whereas five clusters probably represented novel lantipeptides, terpenes, non-ribosomal peptide synthetases (NRPS), and polyketide synthase (PKS) BGCs for which no, or low similarity, BGCs could be identified in the MIBiG database (Table 3). However, antismash-cluster blast analysis revealed that all five clusters are found in numerous strains of $B$. velezensis (data not shown). The BGCs for the sfp-dependent NRPs surfactin, fengycin, bacillaene, and bacillibactin were predicted in strain Bvel1 (Table 3). The surfactin BGC showed a similarity of $82 \%$ compared to the reference. Likewise, BGCs of bacillibactin, subtilosin $\mathrm{A}$, and bacilysin were also present, with a similarity of $100 \%$ to the reference. Cluster 6 harbors two BGCs, one fengycin BGC showing 100\% similarity to the reference, and one BGC showing $88 \%, 100 \%$, and $100 \%$ similarities to known BGCs for the biosynthesis of iturinic-type lipopeptide iturin A, bacillomycin, and mycosubtilin, respectively. The amino acid sequence predicted by the NRPS analysis of the iturinic-type BGC indicated that it belongs to iturin A [34]. BGCs of bacilysin, macrolactin A, and difficidin were also identified, showing $100 \%$ similarity to the references.

Table 3. Biosynthetic genes clusters (BGCs) associated with secondary metabolites found in Bacillus velezensis Bvel1, and their identity with known gene clusters.

\begin{tabular}{|c|c|c|c|c|}
\hline $\begin{array}{l}\text { Cluster } \\
\text { Number }\end{array}$ & Synthetase & $\begin{array}{l}\text { Most Similar } \\
\text { Known Cluster }\end{array}$ & $\begin{array}{c}\text { MIBiG ID } \\
\text { (\% of Genes Show } \\
\text { Similarity) }\end{array}$ & Predicted Size (bp) \\
\hline 1 & NPRS, TransATPKS & Rhizocticin & BGC0000926_c1 (22\%) & 77.624 \\
\hline 2 & NRPS & Surfactin & BGC0000433_c1 (82\%) & 65.407 \\
\hline 3 & PKS-like & Butirosin & BGC0000693_c1 (7\%) & 41.224 \\
\hline 4 & Terpene & - & - & 20.740 \\
\hline 5 & Lanthipeptide-class-II & - & - & 28.889 \\
\hline 6 & TransATPKS & Macrolactin & BGC0000181_c1 (100\%) & 86.366 \\
\hline 7 & TransATPKS-NRPS & Bacillaene & BGC0001089_c1 100(\%) & 109.176 \\
\hline 8 & NPRS, TransATPKS-NRPS & Fengycin & BGC0001095_c1 (93\%) & 114.939 \\
\hline 9 & Terpene & - & - & 41.246 \\
\hline 10 & T3PKS & - & - & 20.739 \\
\hline 11 & TransATPKS & Difficidin & BGC0000176_c1 (100\%) & 106.166 \\
\hline 12 & NPRS & Bacillibactin & BGC0000309_c1 (100\%) & 51.789 \\
\hline 13 & NPRS & Bacilycin & BGC0001184_c1 (100\%) & 41.418 \\
\hline
\end{tabular}

Interestingly, genome mining also allowed the identification of genes encoding for possible antifungal CAZymes in the GH families, such as chitinase (GH18), chitosanase (GH43), endoglucanase (GH51), and $\beta$-glucosidase (GH1), which have the potential to inhibit the growth of plant pathogens [35]. The genome analysis also revealed the presence of genes $(a l s D$, alsR, als $S$ and $b d h A)$ involved in the biosynthesis of acetoin and 2,3 butanediol, volatile metabolites that act as elicitors of induced systemic resistance in plants [36].

\section{Discussion}

In recent years, there has been an increasing demand for environmentally friendly and safe methods for controlling post-harvest diseases caused by fungal pathogens. Biological control agents such as Bacillus sp. and their metabolites have received a lot of attention as complementary or alternative methods to the use of conventional chemical fungicides [1,3-5]. In this study, we showed that the endophytic Bacillus velezensis Bvel1 can be used to control grey mold caused by $B$. cinerea.

Genome sequencing and annotation revealed that the strain Bvell belongs to the $B$. velezensis group. Genome mining revealed that the strain Bvel1 possesses the genetic 
potential to synthesize bioactive secondary metabolites such as fengycin, iturin, surfactin, bacilysin, bacillaene, difficidin, macrolactin, and bacillibactin (siderophore); the compounds endow the producing Bacillus with the potential to effectively antagonize bacterial and fungal plant pathogens and enhance its prospects for functioning as a biocontrol agent [34,35]. Indeed, several studies have highlighted that the successful use of numerous Bacillus strains as biocontrol agents is dependent, not only on their ability to colonize the target tissues, but also on whether the colonizing Bacillus strains possess an intact and functional biosynthetic gene cluster involved in the biosynthesis and secretion of secondary metabolites such as iturin, bacillomycin, fengycin, and surfactin [8,11,14,36-41].

Our data demonstrated that growing Bvel1 cells are capable of constitutively producing and secreting agar-diffusible compounds with a strong antifungal activity, suggesting that secondary metabolites may also be produced and secreted by Bvel1 during its colonization of grape berries. Our chemical analysis revealed that Bvel1 is capable of producing and secreting a mixture of bioactive diffusible secondary metabolites (iturin A2, surfactin A-C13 and -C15 isoforms, oxydifficidin, L-dihydroanticapsin, bacillibactin) and specialized metabolites (azelaic acid) that are known to exert a strong antifungal activity and/or trigger host plant defenses against pathogens. The iturin family lipopeptides are known for their strong antifungal activity [12] and host immune response triggering function in strawberry [42], grapevine [43], and Arabidopsis [10]. Among the iturin A analogues, iturin A2, in a dose-dependent manner, triggers induced systemic resistance (ISR) in chili pepper in a more efficient manner than other iturin analogues [44]. Members of the surfactin family stimulate colonization, biofilm formation, facilitate swarming motility [41], and act as activators of plant defense mechanisms against several microbial pathogens $[10,42,45]$. Among surfactin isoforms, the surfactin A-C15 isoform demonstrates the highest biological and elicitor activity, compared to surfactin A-C12 and -C13 isoforms [46,47]. Dihydroanticapsin, the biosynthetic precursor of bacilysin, is known for its antibacterial and antifungal activity [33]. Oxydifficidin, a derivative of difficidin, exhibits high antimicrobial activity against a wide spectrum of bacteria [12] and may trigger induced systemic resistance in plant systems [10]. The siderophore bacillibactin suppresses fungal growth by chelating the available ferric iron [12]. Azelaic acid is a known antifungal and antibacterial compound [48] that has also been described as an ISR determinant that induces resistance against the P. syringae pathogen in Arabidopsis thaliana [49]. Thus, it is evident that Bacillus velezensis Bvel1 is capable of producing and secreting an excellent mixture of metabolites involved in the direct suppression of plant pathogens and stimulation of plant-host defense responses against fungal and bacterial pathogens.

Our results revealed that the pre-treatment of grape berries with a culture broth containing both Bvel1 bacterial cells and their secreted metabolites resulted in the colonization of wounded grape berries and a remarkable reduction in the grey mold ingress and growth on wounds 3 or 6 days after artificial inoculation. Our data are in agreement with previous observations, where it was demonstrated that the treatment of fruits and vegetables with cell suspensions, cell cultures, CFCS, or CFCS-extracted metabolites from BCAs significantly reduced the ingress and growth of pre-harvest and post-harvest pathogenic fungi [50-52]. However, recent studies have demonstrated that effective biocontrol is achieved when the concentration of applied/produced pure elicitors such as plipastatin, iturin, and bacillomycin D on the target tissue is in micromolar amounts $(10-50 \mu \mathrm{M})[16,44,47,53]$; a concentration that is almost equal to their MIC values [16,51].

Previous studies have reported that the treatment of plant tissues (fruits, leaves) with cell suspensions, cell cultures, and cell free culture supernatant from BCAs gave very low values $(<1-2 \mu \mathrm{g} / \mathrm{g}$ plant tissue) $[14,54,55]$, raising questions about how to achieve the accumulation of active metabolites near or over the threshold levels required for antibiosis and/or induction of host plant defense mechanisms [54]. Recent studies have shown that bacterial colonization may generate microcolonies on the target tissue, where secondary metabolites are accumulated in micromolar amounts in microniches [56]. In line with this perspective, it could be assumed that both the secreted metabolites contained in 
Bvel1 culture and those possibly produced in situ by the colonizing bacteria, may allow the generation of microniches on the target tissue, where the metabolites accumulate in micromolar quantities, sufficient to trigger the host's induced resistance and, moreover, to inhibit the ingress and growth of invading or latent fungal pathogens.

In conclusion, the results of this study revealed that the strain Bvel1 inhibited the mycelial growth of $B$. cinerea in vitro and also reduced disease incidence and disease development in red globe grapes caused by B. cinerea. This was likely because of its colonization ability and its capacity to constitutively biosynthesize and secrete metabolites such as iturin A2, surfactin A-C15, and azelaic acid. These attributes may allow Bvel1 to generate a hostile environment for the incoming pathogen, through competition for nutrients or space on the plant surface, generating microniches of high antibiotic activity on the fruit surface and inducing plant-mediated responses. However, further analyses will be needed to understand the functional role of metabolites produced by B. velezensis Bvel1 and how they are able to modulate the defense networks of plants. In this context, emphasis should be placed on metabolites such as azelaic acid, because of its potential use as a chemical elicitor of ISR-responses.

\section{Materials and Methods}

\subsection{Isolation of Endophytic Bacteria-Microorganisms and Culture Conditions}

Secondary roots were excised from four healthy olive trees (Olea europaea cv Koroneiki) located at the Agricultural University of Athens Experimental station ( 37.59 N 23.42 E). The surface sterilization of root segments (40-50 mm length) was performed according to [57]. Selected roots were rinsed with tap water, dried with absorbent papers, and then immersed in $70 \%$ ethanol solution for $1 \mathrm{~min}$, followed by immersion in a solution containing $5 \%$ commercial bleach and $0.1 \%$ Tween 20 for $3 \mathrm{~min}$. The tissues were immersed again in 70\% ethanol for $30 \mathrm{~s}$ and then were rinsed 5 times with sterilized double distilled water. After rinsing, the samples were cut into smaller fragments $(4-5 \mathrm{~mm})$ with a sterile razor blade and crushed with sterile mortar and pestle in sterile $10 \mathrm{mM} \mathrm{MgSO}_{4}$-solution (1 g roots in $6 \mathrm{~mL}$ ). Serial 10-fold dilutions of the suspensions were prepared, and $100 \mu \mathrm{L}$ aliquots were plated on Nutrient agar (NA) plates. To verify the surface sterility of the roots, $100 \mu \mathrm{L}$ of the last rinsing water was plated on NA plates amended with cycloexamide $(50 \mu \mathrm{g} / \mathrm{mL})$ and incubated at $28^{\circ} \mathrm{C}$ for 12-14 days. Each bacterial colony was then subcultured to obtained a pure culture. Out of the 89 endophytic bacterial strains isolated from plant roots, 36 distinct morphotypes were selected for further studies. Strains were routinely maintained on NA at $4{ }^{\circ} \mathrm{C}$, stored long-term as a $20 \%$ glycerol stock at $-80{ }^{\circ} \mathrm{C}$, and cultured in nutrient broth (NB) or NA at $30^{\circ} \mathrm{C}$ for $48 \mathrm{~h}$ before experimental use.

The pathogen Botrytis cinerea Pers BPIC2585 was obtained from the Collection of Phytopathogenic Fungi (Benaki Phytopathological Institute, Kifissia, Athens, Greece) and was stored on potato dextrose agar (PDA) at $4{ }^{\circ} \mathrm{C}$. The pathogen was cultured on PDA at $25^{\circ} \mathrm{C}$ before any experimental use, and virulence was retained by regular transfers through grape berries. A conidial suspension was obtained by flooding the fungal culture with sterile distilled water, rubbing the mycelium, and filtering through a sterile nylon gauze (mesh of $200 \mu \mathrm{m}$ ). The number of conidia was counted in a hemocytometer, and the suspension was adjusted with sterile distilled water to a final concentration of $1.0 \times 10^{6}$ conidia $/ \mathrm{mL}$.

\subsection{In Vitro Antagonistic Activity of Bacillus velezensis Bvel1 against B. cinerea}

The antagonistic activity of the isolated bacteria were tested in vitro by dual culture method, as previously described [58]. Briefly, a mycelial disc (5-mm diameter) was obtained from the colony edge of 7-day-old culture and was transferred onto a NA plate. Ten $\mu \mathrm{L}$ of a bacterial culture grown in Nutrient Broth (NB) for 16-18 h was spotted at a $3 \mathrm{~cm}$ distance from the mycelial disc. An NA plate containing the pathogen alone was used as a control. Cultures were maintained at $25^{\circ} \mathrm{C}$ for 6 days, and the antagonistic effect was evaluated by measuring the distance between the edges of the growing mycelium and the antagonistic bacterium. This region was defined as an inhibition zone. The colony radius of $B$. cinerea 
was measured in treatment and control. The inhibition rate of mycelium growth of strain Bvel1 against strains of $B$. cinerea was calculated using the following formula: Inhibition rate $(\%)=((\mathrm{A}-\mathrm{B}) / \mathrm{A}) \times 100$; where $\mathrm{A}$ represents the colony diameter of the control and $\mathrm{B}$ represents the colony diameter of each treatment.

\subsection{Extraction of Bacillus velezensis Bvel1 Secreted Agar-Diffusible Compounds}

NA plates were inoculated with $200 \mu \mathrm{L}$ of pre-grown bacterial culture, containing or not a mycelial disc (5-mm diameter) from the colony edge of a 7-day-old B. cinerea culture. NA plates containing only a bacterial inoculation were used as a control treatment. The plates were incubated at $25^{\circ} \mathrm{C}$ for 6 days. The extraction of agar diffusible compounds secreted by Bvle1, henceforth referred to as Bvel1 extracts of secreted compounds (ESC) and specifically as ESC1 when grown singly or ESC2 during the interaction with $B$. cinerea, was conducted as described in the protocol of Bertrand et al. [59] and Cawoy et al. [60]. Briefly, $1.5-2.0 \mathrm{~cm}$ width blocks of NA medium were excised from an area located in front of the bacterial antagonist without fungal pathogen or the inhibition zone between the bacterial and fungal colony, cut into small pieces, mixed thoroughly with ethyl acetate, and put in a water-bath sonicator (Elmasonic S30H, Elma Schmidbauer GmbH, Singen, Germany) at room temperature for $30 \mathrm{~min}$. The organic phase was separated and the samples were dried in a speed vacuum evaporator (Rotavapor R-114, BÜCHI Labortechnik AG, Flawil, Switzerland), re-dissolved in $1000 \mu \mathrm{L}$ of ultrapure methanol, filtered using a $0.22 \mu \mathrm{m}$ filter, and saved at $-80^{\circ} \mathrm{C}$ until testing or chemical analysis using a UHPLC-ESI HRMS (orbitrap) high resolution mass spectrometer (Thermo Scientific, San Jose, CA, USA).

\subsection{In Vitro Antagonistic Activity of Secreted Agar-Diffusible Compounds from Strain Bvel1 against $B$. cinera}

The well-diffusion confrontation method was used to detect and measure the antagonistic effect of ESC1 and ESC2 on B. cinerea mycelium growth [61]. Briefly, two holes with a diameter of $3 \mathrm{~mm}$ were punched aseptically with a sterile cork borer on antidiametric points of a NA plate, at a 2-cm distance from each edge. A mycelial disc (5-mm diameter) from the colony edge of a 7-day-old $B$. cinerea culture was inoculated in between. Then, $20 \mu \mathrm{L}$ of ESC1 or ESC2 was added to one hole and $20 \mu \mathrm{L}$ methanol to the other (control) and the NA plate was incubated at $25^{\circ} \mathrm{C}$. After the 5-day co-incubation, the zones of inhibition were recorded. The antifungal activity was determined by observing the inhibition zone of fungal growth around the hole.

\subsection{TLC-Bioautography of Bvel1 Secreted Compounds}

Thin layer chromatography (TLC) analysis of ESC1 and ESC2 and bioautography was conducted as described previously [54]. TLC was performed using silica gel 60 F254 plates $(20 \times 20 \mathrm{~cm}$; layer thickness, $0.20 \mathrm{~mm}$; Merck) and chloroform-methanol-water (65:25:4, $v / v / v$ ) as mobile phase. The TLC-bioautography assay was performed using the B. cinerea strain as an indicator strain. After migration, TLC plates were covered with PDA $(0.8 \% w / v)$ previously inoculated with the indicator strain $\left(10^{5}\right.$ spores $\left./ \mathrm{mL}\right)$ and incubated at $25{ }^{\circ} \mathrm{C}$ for $24 \mathrm{~h}$. Viable cells were visualized after spraying with MTT (3-(4,5-dimethylthiazol-2-yl)2,5-diphenyltetrazolium bromide) at a concentration of $5 \mathrm{mg} / \mathrm{mL}$. Clear zones indicated the presence of bioactive compounds. The Rf value was calculated using the formula: $\mathrm{Rf}$ value $=$ distance travelled by the solute/distance travelled by the solvent.

\subsection{Orbitrap High Resolution Mass Spectrometry (UHPLC-HRMS) Analysis of Bvel1 Secreted Compounds}

For the investigation of the chemical profiling of the ESC1 extracts a Q-Exactive Orbitrap platform (Thermo Fisher Scientific, San Jose, CA, USA) connected to a Dionex Ultimate 3000 UHPLC system (Thermo Scientific ${ }^{\mathrm{TM}}$ Dionex $^{\mathrm{TM}}$, Sunnyvale, CA, USA) was employed. A Hypersil Gold UPLC C18 $(2.1 \times 150 \mathrm{~mm}, 1.9 \mu \mathrm{m})$ reversed phased column (Thermo Fisher Scientific, San Jose, CA, USA) was used. Sample analysis was carried out in both positive (ESI+) and negative (ESI-) ion mode. Eluent A (ultrapure water with $0.1 \%$ 
formic acid) and B (acetonitrile) were used in a gradient mode of $30 \mathrm{~min}$, as follows: 0 to $21 \mathrm{~min}$ : 95\% A: 5\% B, 21 to $24 \mathrm{~min}$ : 5\% A: 95\% B, 24 to $30 \mathrm{~min}: 95 \%$ A: 5\% B. The flow rate was $0.22 \mathrm{~mL} / \mathrm{min}$ and data acquisition was performed on a mass range of 115-1500 Da on profile mode. The conditions for the HRMS for both negative and positive modes were set as follows: capillary temperature, $350{ }^{\circ} \mathrm{C}$; spray voltage, $2.7 \mathrm{kV}$; S-lense Rf level, $50 \mathrm{~V}$; sheath gas flow, 40 arb. units; aux gas flow, 5 arb. units; aux. gas heater temperature, $50{ }^{\circ} \mathrm{C}$. The resolution for full scan analysis was set at 70,000, whereas for the data dependent acquisition mode the resolution was 35,000, allowing for MS/MS fragmentation of the three most intense ions. The stepped normalized collision energy was set at 35,60, and 100. The column temperature was kept at $40^{\circ} \mathrm{C}$, while the sample tray temperature was set at $4{ }^{\circ} \mathrm{C}$. The resulting data was processed through Compound Discovered version 2.1 (Thermo Fisher Scientific, San Jose, CA, USA). For metabolite annotation the online mzCloud library, the public chemical database PubChem (NCBI) was used, taking into consideration the isotopic and MS/MS fragmentation pattern and applying an $m / z$ tolerance of $\pm 5 \mathrm{ppm}$.

\subsection{In Vivo Antagonistic Activity of Bvel1 against B. cinerea on Grape Berries}

For the in vivo antifungal activity test of the strain Bvel1, red globe grapes (Vitis vinifera L cv. Red Globe) were surface sterilized with ethanol for $1 \mathrm{~min}, 0.1 \%$ bleach for $1 \mathrm{~min}$, and $70 \%$ ethanol for $2 \mathrm{~min}$, rinsed with sterile water and wounded with a sterile $21 \mathrm{G}$ needle. The grapes were at the stage of berry maturation. Then, $10 \mu \mathrm{L}$ of $\mathrm{ddH}_{2} \mathrm{O}$ or $10 \mu \mathrm{L}$ of the strain Bvel1 suspension (vegetative cells, endospores and supernatant) at $10^{6}$ or $10^{8} \mathrm{CFU} / \mathrm{mL}$ and $10 \mu \mathrm{L}$ of the pathogen suspension $\left(1.1 \times 10^{6}\right.$ conidia $\left./ \mathrm{mL}\right)$ was placed on the wounds. The treatments with cell cultures were added either $24 \mathrm{~h}$ before or $24 \mathrm{~h}$ after fungal inoculation. The grape berries were stored in enclosed plastic trays to maintain a high relative humidity (approximately 80\%) in a ventilated cabinet at $25^{\circ} \mathrm{C}$ for 6 days. There were 10 fruits with three technical replicates per treatment, and the experiment was conducted independently three times.

The number of infected grapes was recorded after 3 and 6 days of artificial inoculation, and disease incidence (DI) was calculated using the following formula: DI (\%) = number of infected grape berries/total number of berries $\times 100$. Grape berries were assessed under a stereoscope, and each berry was given a value using a $0-5$ rating scale, as proposed by Calvo and co-workers [62], where: $0=$ no visible symptoms; $1=$ visible lesion covering less than $25 \%$ of the fruit surface; $2=25$ to $50 \% ; 3=50$ to $75 \% ; 4=75$ to $100 \%$. Disease severity (\%) was calculated according to the Townsend-Heuberger formula [63]:

$$
\text { DSI }(\%)=\frac{\Sigma(d i)}{D Z} \times 100
$$

where DSI is the disease severity index, $d$ is the number of fruits in the scale with different disease grades, $i$ is the scale (1-to- 4 ) values, $D$ is the total number of fruits examined, and $Z$ is the highest scale value.

\subsection{Colonization of the Strain Bvel1 on Wounded Grape Berries}

Grape berries samples were wounded according to the previous description. The wounds were treated with aliquots $(10 \mu \mathrm{L})$ of cell culture of the Bvel1 at $1 \times 10^{8} \mathrm{CFU} / \mathrm{mL}$ alone or challenge-inoculated after $1 \mathrm{~d}$ with a conidial suspension of $B$. cinerea $\left(1 \times 10^{6}\right.$ spores $\left.\mathrm{mL}^{-1}\right)$, and stored at $25^{\circ} \mathrm{C}$ for $5 \mathrm{~d}$. The tissue samples were excised with a sterile cork borer $(0.4 \mathrm{~cm}$ diameter and $0.4 \mathrm{~cm}$ deep) and ground with a mortar and pestle in $10 \mathrm{~mL}$ of sterile phosphate-buffered saline (PBS; $\mathrm{KH}_{2} \mathrm{PO}_{4}, 0.27 \mathrm{~g} / \mathrm{L} ; \mathrm{KCl} 0.2 \mathrm{~g} / \mathrm{L}$; $\mathrm{NaCl} 8 \mathrm{~g} / \mathrm{L} ; \mathrm{Na}_{2} \mathrm{HPO}_{4} 1.42 \mathrm{~g} / \mathrm{L} ; \mathrm{pH}$ 7.0). The number of bacteria was determined by dilution-plating at $48 \mathrm{~h}$ after incubation on NA plates with $50 \mu \mathrm{g} / \mathrm{mL}$ chloramphenicol at $30{ }^{\circ} \mathrm{C}$ and expressed as $\log 10 \mathrm{CFU} /$ wound. There were 8 fruits with three technical replicates per treatment, and the experiment was conducted independently three times. 


\subsection{Genome Sequencing}

Genomic DNA was isolated from an overnight grown culture of Bacillus sp. strain Bvel1 using a PureLink ${ }^{\circledR}$ Genomic DNA Mini Kit (Thermo Fisher Scientific, Carlsbad, CA, USA). The genome of strain Bvel1 was sequenced by SNPsaurus (Eugene, OR, USA) using an Illumina HiSeq 2000 platform, following their standard workflow for library preparation, read trimming, and assembly. This workflow used a Nextera XT DNA Library Prep Kit for library generation, followed by sequencing that generated 2x150-bp paired-end reads, followed by trimming of adaptors with BBDuk, and then assembly with SPAdes-3.12.0 using default parameters [64]. This workflow generated a total of 1,332,238 trimmed paired reads and $399.6 \mathrm{Mbp}$ of sequence ( $>60$-fold coverage). The final de novo genome of strain Bvel1 was assembled in 8 scaffolds with size of 3,945,125 bp and a plasmid with size of 14,419 bp. The whole genome project was deposited at the DDBJ/EMBL/GeneBank under the accession number JAAOBZ000000000, Bioproject: PRJNA610721, BioSample: SAMN14309916.

The chromosomal map of Bacillus velezensis Bvel1 was drawn using DNAPlotter [65]. Scaffolds were ordered against the reference genome of Bacillus velezensis LB002. Scaffolds/chromosome alignment was performed with progressive MAUVE [66], while the alignment of plasmids was calculated and drawn using the Easyfig tool [67]. Strain identity was established by The Type (Strain) Genome server (TYGS) platform available at https: / /tygs.dsmz.de (accessed on 13 August 2021) [23] and by calculating the digital DNA:DNA hybridization ( $\mathrm{dDDH})$ using the genome-to-genome distance calculator website service (GGDC 2.1) [68] and the orthologous average nucleotide identity (OrthoANI) [69].

\subsection{Functional Genome Analysis}

The proteome of the Bacillus velezensis Bvel1 was analyzed against the Kyoto encyclopedia of genes and genomes (KEGG) [70], cluster of orthologous genes (COG) [71], and carbohydrate-active enzymes (CAZy) [72] databases by BlastKOALA [73], WebMGA [74], and dbCAN2 [75]. Graphical representation of the main metabolic pathways of Bacillus sp. Bvel1 was performed with KEGG mapper [76]. A secondary metabolite analysis was performed using the antiSMASH database [77].

\subsection{Data Analysis}

The software ImageJ (https://imagej.nih.gov/ij/ (accessed on 15 June 2021)) was used for measurements on the detached fruit. Statistical analyses and plots were carried out with IBM SPSS Statistics for Windows, version 25 (IBM Corp., Armonk, NY, USA) and Sigma Plot, version 12.0 (Systat Software, San Jose, CA, USA), respectively. Data of percentages were arcsine transformed and data on bacterial population were transformed to the logarithmic scale before performing an independent samples $t$ test $(p$-value $<0.05)$. Plots depict average values with standard deviation as error bars, and asterisks indicate statistical differences.

Supplementary Materials: The following are available online at https:/ / www.mdpi.com/article/10 .3390 / plants10081716/s1, Figure S1: Circular map of the Bacillus velezensis Bvel1 genome, Figure S2: Functional analysis of the Bacillus velezensis Bvel1 proteome, Figure S3: Metabolic map of Bacillus velezensis Bvel1.

Author Contributions: Conceptualization, P.K., A.V.; methodology, E.B., A.V., K.N., K.P., P.K., E.-E.T., P.C.T.; writing—original draft preparation P.K., K.N.; elaborating the research questions, analyzing the data, formal analysis, software, writing and reviewing the article K.N., E.-E.T., P.C.T., C.D., E.B., A.S., D.K., E.M., A.V., K.P., funding acquisition P.K., A.V., E.M. All authors have read and agreed to the published version of the manuscript.

Funding: This work was partially funded by the project «The foremost flagship in Greece "vine-

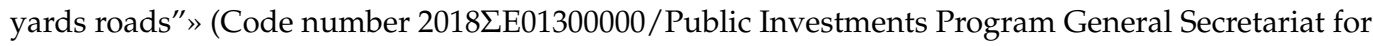
Research and Technology), Greek Ministry of Education and Religious Affairs.

Institutional Review Board Statement: Not applicable. 
Informed Consent Statement: Not applicable.

Data Availability Statement: Bacterial strain data analyzed in this study is available in the NCBI database. The Bacillus sp. Bvel1 whole genome project has the BioProject: PRJNA610721, BioSample: SAMN14309916, accession number JAAOBZ000000000.

Conflicts of Interest: The authors declare that they have no conflict of interest.

\section{References}

1. Poveda, J.; Barquero, M.; González-Andrés, F. Insight into the microbiological control strategies against Botrytis cinerea using systemic plant resistance activation. Agronomy 2020, 10, 1822. [CrossRef]

2. Jiang, C.M.; Shi, J.L.; Liu, Y.L.; Zhu, C.Y. Inhibition of Aspergillus carbonarius and fungal contamination in table grapes using Bacillus subtilis. Food Control 2014, 35, 41-48. [CrossRef]

3. Pertot, I.; Giovannini, O.; Benanchi, M.; Caffi, T.; Rossi, V.; Mugnai, L. Combining biocontrol agents with different mechanisms of action in a strategy to control Botrytis cinerea on grapevine. Crop Prot. 2017, 97, 85-93. [CrossRef]

4. Fedele, G.; Brischetto, C.; Rossi, V. Biocontrol of Botrytis cinerea on grape berries as influenced by temperature and humidity. Front. Plant Sci. 2020, 11, 1232. [CrossRef]

5. Fira, D.; Dimkic, I.; Beric, T.; Lozo, J.; Stankovic, S. Biological control of plant pathogens by Bacillus species. J. Biotechnol. 2018, 285, 44-55. [CrossRef]

6. Cedeño, L.R.M.; Mosqueda, M.d.C.O.; Lara, P.D.L.; Cota, F.I.P.; Villalobos, S.d.L.S.; Santoyo, G. Plant growth-promoting bacterial endophytes as biocontrol agents of pre- and post-harvest diseases: Fundamentals, methods of application and future perspectives. Microbiol. Res. 2021, 242, 126612. [CrossRef] [PubMed]

7. Keswani, C.; Singh, H.B.; García-Estrada, C.; Caradus, J.; He, Y.W.; Mezaache-Aichour, S.; Glare, T.R.; Borriss, R.; Sansinenea, E. Antimicrobial secondary metabolites from agriculturally important bacteria as next-generation pesticides. Appl. Microbiol. Biotechnol. 2020, 104, 1013-1034. [CrossRef]

8. Arrebola, E.; Jacobs, R.; Korsten, L. Iturin A is the principal inhibitor in the biocontrol activity of Bacillus amyloliquefaciens PPCB004 against post-harvest fungal pathogens. J. Appl. Microbiol. 2010, 108, 386-395. [CrossRef]

9. Garcia-Gutierrez, L.; Zeriouh, H.; Romero, D.; Cubero, J.; de Vicente, A.; and Pérez-García, A. The antagonistic strain Bacillus subtilis UMAF6639 also confers protection to melon plants against cucurbit powdery mildew by activation of jasmonate and salicylic acid-dependent defence responses. Microb. Biotechnol. 2013, 6, 264-274. [CrossRef]

10. Wu, G.; Liu, Y.; Xu, Y.; Zhang, G.; Shen, Q.; Zhang, R. Exploring elicitors of the beneficial rhizobacterium Bacillus amyloliquefaciens SQR9 to induce plant systemic resistance and their interactions with plant signalling pathways. Mol. Plant Microbe Interact. 2018, 31, 560-567. [CrossRef] [PubMed]

11. Li, Y.; Héloir, M.C.; Zhang, X.; Geissler, M.; Trouvelot, S.; Jacquens, L.; Henkel, M.; Su, X.; Fang, X.; Wang, Q. Surfactin and fengycin contribute to the protection of a Bacillus subtilis strain against grape downy mildew by both direct effect and defence stimulation. Mol. Plant Pathol. 2019, 20, 1037-1050. [CrossRef]

12. Caulier, S.; Nannan, C.; Gillis, A.; Licciardi, F.; Bragard, C.; Mahillon, J. Overview of the antimicrobial compounds produced by members of the Bacillus subtilis group. Front. Microbiol. 2019, 10, 302. [CrossRef]

13. Ongena, M.; Jacques, P. Bacillus lipopeptides: Versatile weapons for plant disease biocontrol. Trends Microbiol. 2008, 16, 115-125. [CrossRef]

14. Romero, D.; De Vicente, A.; Rakotoaly, R.H.; Dufour, S.E.; Veening, J.-W.; Arrebola, E.; Cazorla, F.M.; Kuipers, O.P.; Paquot, M.; Perez-Garcia, A. The Iturin and Fengycin families of lipopeptides are key factors in antagonism of Bacillus subtilis toward Podosphaera fusca. Mol. Plant Microbe Interact. 2007, 20, 430-440. [CrossRef] [PubMed]

15. Waewthongrak, W.; Leelasuphakul, W.; McCollum, G. Cyclic Lipopeptides from Bacillus subtilis ABS-S14 Elicit Defense-Related Gene Expression in Citrus Fruit. PLoS ONE 2014, 9, e109386. [CrossRef] [PubMed]

16. Lin, F.; Xue, Y.; Huang, Z.; Jiang, M.; Lu, F.; Bie, X.; Miao, S.; Lu, Z. Bacillomycin D inhibits growth of Rhizopus stolonifer and induces defense-related mechanism in cherry tomato. Appl. Microbiol. Biotechnol. 2019, 103, 7663-7674. [CrossRef]

17. Farzand, A.; Moosa, A.; Zubair, M.; Khan, A.R.; Massawe, V.C.; Tahir, H.A.S.; Sheikh, T.M.M.; Ayaz, M.; Gao, X. Suppression of Sclerotinia sclerotiorum by the induction of systemic resistance and regulation of antioxidant pathways in tomato using fengycin produced by Bacillus amyloliquefaciens FZB42. Biomolecules 2019, 9, 613. [CrossRef] [PubMed]

18. Huang, X.; Ren, J.; Li, P.; Feng, S.; Dong, P.; Ren, M. Potential of microbial endophytes to enhance the resistance to postharvest diseases of fruit and vegetables. J. Sci. Food Agric. 2021, 101, 1744-1757. [CrossRef] [PubMed]

19. Lastochkina, O.; Pusenkova, L.; Garshina, D.; Yuldashev, R.; Shpirnaya, I.; Kasnak, C.; Palamutoglu, R.; Mardanshin, I.; Garipova, S.; Sobhani, M.; et al. The effect of endophytic bacteria Bacillus subtilis and salicylic acid on some resistance and quality traits of stored Solanum tuberosum L. Tubers infected with Fusarium dry rot. Plants 2020, 9, 738. [CrossRef] [PubMed]

20. Chaouachi, M.; Marzouk, T.; Jallouli, S.; Elkahoui, S.; Gentzbittel, L.; Ben, C.; Dj'ebali, N. Activity assessment of tomato endophytic bacteria bioactive compounds for the postharvest biocontrol of Botrytis cinerea. Post. Biol. Technol. 2021, 172, 111389. [CrossRef] 
21. Damasceno, C.L.; Duarte, E.A.A.; dos Santos, L.B.P.R.; de Oliveira, T.A.S.; de Jesus, F.N.; de Oliveira, L.M.; Góes-Neto, A.; Soares, A.C.F. Postharvest biocontrol of anthracnose in bananas by endophytic and soil rhizosphere bacteria associated with sisal (Agave sisalana) in Brazil. Biol. Control 2020, 137, 104016. [CrossRef]

22. Fan, B.; Blom, J.; Klenk, H.P.; Borriss, R. Bacillus amyloliquefaciens, Bacillus velezensis, and Bacillus siamensis form an "Operational Group, B. amyloliquefaciens" within the B. subtilis species complex. Front. Microbiol. 2017, 8, 22. [CrossRef]

23. Meier-Kolthoff, J.P.; Göker, M. TYGS is an automated high-throughput platform for state-of-the-art genome-based taxonomy. Nat. Commun. 2019, 10, 2182. [CrossRef]

24. Lefort, V.; Desper, R.; Gascuel, O. FastME 2.0: A comprehensive, accurate, and fast distance-based phylogeny inference program. Mol. Biol. Evol. 2015, 32, 2798-2800. [CrossRef]

25. Farris, J.S. Estimating phylogenetic trees from distance matrices. Am. Nat. 1972, 106, 645-667. [CrossRef]

26. Luo, C.; Zhou, H.; Zou, J.; Wang, X.; Zhang, R.; Xiang, Y.; Chen, Z. Bacillomycin L and surfactin contribute synergistically to the phenotypic features of Bacillus subtilis 916 and the biocontrol of rice sheath blight induced by Rhizoctonia solani. Appl. Microbiol. Biotechnol. 2015, 99, 1897-1910. [CrossRef] [PubMed]

27. Janek, T.; Drzymała, K.; Dobrowolski, A. In vitro efficacy of the lipopeptide biosurfactant surfactin-C15 and its complexes with divalent counterions to inhibit Candida albicans biofilm and hyphal formation. Biofouling 2020, 36, 210-221. [CrossRef] [PubMed]

28. Wang, Y.; Zhang, C.; Liang, J.; Wu, L.; Gao, W.; Jiang, J. Iturin A extracted from Bacillus subtilis WL2 Affects Phytophthora infestans via cell structure disruption, oxidative stress, and energy supply dysfunction. Front. Microbiol. 2020, 11, 2205.

29. Parker, J.B.; Walsh, C.T. Action and timing of $\mathrm{BacC}$ and $\mathrm{BacD}$ in the late stages of biosynthesis of the dipeptide antibiotic bacilysin. Biochemistry 2013, 52, 889-901. [CrossRef]

30. Im, S.M.; Yu, N.H.; Joen, H.W.; Kim, S.O.; Park, H.W.; Park, A.R.; Kim, J.C. Biological control of tomato bacterial wilt by oxydifficidin and difficidin-producing Bacillus methylotrophicus DR-08. Pest. Biochem. Physiol. 2020, 163, 130-137. [CrossRef] [PubMed]

31. Cheon, H.I.; Yeo, M.S.; Kim, K.M.; Kang, J.S.; Pyo, J. Determination of siderophore from Bacillus mojavensis using liquid chromatography quadrupole time-of-flight tandem mass spectrometry. J. Life Sci. 2019, 29, 19.

32. Javvadi, S.G.; Cescutti, P.; Rizzo, R.; Lonzarich, V.; Navarini, L.; Licastro, D.; Venturi, V. The spent culture supernatant of Pseudomonas syringae contains azelaic acid. BMC Microbiol. 2018, 18, 199. [CrossRef]

33. Wang, T.; Liu, X.H.; Wu, M.B.; Ge, S. Molecular insights into the antifungal mechanism of bacilysin. J. Mol. Model. 2018, 24, 1-9. [CrossRef] [PubMed]

34. Dunlap, C.A.; Bowman, M.J.; Rooney, A.P. Iturinic lipopeptide diversity in the Bacillus subtilis species group-Important antifungals for plant disease biocontrol applications. Front. Microbiol. 2019, 10, 1794. [CrossRef] [PubMed]

35. Xu, W.; Zhang, L.; Goodwin, P.H.; Xia, M.; Zhang, J.; Wang, Q.; Liang, J.; Sun, R.; Wu, C.; Yang, L. Isolation, identification, and complete genome assembly of an endophytic Bacillus velezensis YB-130, potential biocontrol agent against Fusarium graminearum. Front. Microbiol. 2020, 11, 598285. [CrossRef] [PubMed]

36. Ryu, C.M.; Farag, M.A.; Hu, C.H.; Reddy, M.S.; Kloepper, J.W.; Pare, P.W. Bacterial volatiles induced systemic resistance in Arabidopsis. Plant Physiol. 2004, 134, 1017-1026. [CrossRef]

37. Raymaekers, K.; Ponet, L.; Holtappels, D.; Berckmans, B.; Cammue, B.P.A. Screening for novel biocontrol agents applicable in plant disease management-A review. Biol. Control 2020, 144, 104240. [CrossRef]

38. Kohl, J.; Kolnaar, R.; Ravensberg, W.J. Mode of action of microbial biological control agents against plant diseases: Relevance beyond efficacy. Front. Plant Sci. 2019, 10, 845. [CrossRef]

39. Zeriouh, H.; Romero, D.; García-Gutiérrez, L.; Cazorla, F.M.; de Vicente, A.; Pérez-García, A. The Iturin-like lipopeptides are essential components in the biological control arsenal of Bacillus subtilis against bacterial diseases of cucurbits. Mol. Plant Microb. Interact. 2011, 24, 1540-1552. [CrossRef]

40. Zeriouh, H.; de Vicente, A.; Pérez-García, A.; Romero, D. Surfactin triggers biofilm formation of Bacillus subtilis in melon phylloplane and contributes to the biocontrol activity. Environ. Microbiol. 2014, 16, 2196-2211. [CrossRef]

41. Fan, H.; Zhang, Z.; Li, Y.; Zhang, X.; Duan, Y.; Wang, Q. Biocontrol of bacterial fruit blotch by Bacillus subtilis 9407 via surfactinmediated antibacterial activity and colonization. Front. Microbiol. 2017, 8, 1973. [CrossRef]

42. Yamamoto, S.; Shiraishi, S.; Suzuki, S. Are cyclic lipopeptides produced by Bacillus amyloliquefaciens S13-3 responsible for the plant defence response in strawberry against Colletotrichum gloeosporioides? Lett. Appl. Microbiol. 2015, 60, 379-386. [CrossRef] [PubMed]

43. Farace, G.; Fernandez, O.; Jacquens, L.; Coutte, F.; Krier, F.; Jacques, P.; Clément, C.; Barka, E.A.; Jacquard, C.; Dorey, S. Cyclic lipopeptides from Bacillus subtilis activate distinct patterns of defence responses in grapevine. Mol. Plant Pathol. 2015, 16, 177-187. [CrossRef]

44. Park, K.; Park, Y.-S.; Ahamed, J.; Dutta, S.; Ryu, H.; Lee, S.-H.; Balaraju, K.; Manir, M.; Moon, S.-S. Elicitation of induced systemic resistance of chili pepper by iturin A analogs derived from Bacillus vallismortis EXTN-1. Can. J. Plant Sci. 2016, 96, 564-570. [CrossRef]

45. Rodríguez, J.; Tonelli, M.L.; Figueredo, M.S.; Ibáñez, F.; Fabra, A. The lipopeptide surfactin triggers induced systemic resistance and priming state responses in Arachis hypogaea L. Eur. J. Plant Pathol. 2018, 152, 845-851. [CrossRef]

46. Bacon, C.W.; Hinton, D.M.; Mitchell, T.R.; Snook, M.E.; Olubajo, B. Characterization of endophytic strains of Bacillus mojavensis and their production of surfactin isomers. Biol. Control 2012, 62, 1-9. [CrossRef] 
47. Pršic, J.; Ongena, M. Elicitors of plant immunity triggered by beneficial bacteria. Front. Plant Sci. 2020, 11, 1675. [CrossRef] [PubMed]

48. Siedler, S.; Balti, R.; Neves, A.R. Bioprotective mechanisms of lactic acid bacteria against fungal spoilage of food. Curr. Opin. Biotechnol. 2019, 56, 138-146. [CrossRef]

49. Cecchini, N.M.; Roychoudhry, S.; Speed, D.J.; Steffes, K.; Tambe, A.; Zodrow, K.; Konstantinoff, K.; Jung, H.W.; Engle, N.L.; Tschaplinski, T.J.; et al. Underground azelaic acid-conferred resistance to Pseudomonas syringae in Arabidopsis. Mol. Plant Microbe Interact. 2019, 32, 86-94. [CrossRef]

50. Zhang, B.; Li, Y.; Zhang, Y.Y.; Qiao, H.T.; He, J.T.; Yuan, Q.; Chen, X.; Fan, J. High-cell-density culture enhances the antimicrobial and freshness effects of Bacillus subtilis S1702 on table grapes (Vitis vinifera cv. Kyoho). Food Chem. 2019, 286, 541-549. [CrossRef]

51. Pellegrini, M.; Pagnani, G.; Bernardi, M.; Mattedi, A.; Spera, D.M.; Del Gallo, M. Cell-free supernatants of plant growth-promoting bacteria: A review of their use as biostimulant and microbial biocontrol agents in sustainable. Sustainability 2020, $12,9917$. [CrossRef]

52. Dimopoulou, A.; Theologidis, I.; Liebmann, B.; Kalantidis, K.; Vassilakos, N.; Skandalis, N. Bacillus amyloliquefaciens MBI600 differentially induces tomato defense signaling pathways depending on plant part and dose of application. Sci. Rep. 2019, 9, 19120. [CrossRef]

53. Ma, Z.; Hu, J. Plipastatin A1 produced by a marine sediment-derived Bacillus amyloliquefaciens SH-B74 contributes to the control of gray mold disease in tomato. 3 Biotech 2018, 8, 125. [CrossRef] [PubMed]

54. Calvo, H.; Mendiara, I.; Arias, E.; Blanco, D.; Venturini, M.E. The role of iturin A from B. amyloliquefaciens BUZ-14 in the inhibition of the most common postharvest fruit rots. Food Microbiol. 2019, 82, 62-69. [CrossRef]

55. Touré, Y.; Ongena, M.; Jacques, P.; Guiro, A.; Thonart, P. Role of lipopeptides produced by Bacillus subtilis GA1 in the reduction of grey mould disease caused by Botrytis cinerea on apple. J. Appl. Microbiol. 2004, 96, 1151-1160. [CrossRef]

56. Debois, D.; Jourdan, E.; Smargiasso, N.; Thonart, P.; De Pauw, E.; Ongena, M. Spatiotemporal monitoring of the antibiome secreted by Bacillus biofilms on plant roots using MALDI mass spectrometry imaging. Anal. Chem. 2014, 86, 4431-4438. [CrossRef] [PubMed]

57. Kusari, S.; Lamshöft, M.; Zühlke, S.; Spiteller, M. An endophytic fungus from Hypericum perforatum that produces hypericin. J. Nat. Prod. 2008, 71, 159-162. [CrossRef]

58. Cheng, X.; Ji, X.; Li, J.; Qi, W.; Qiao, K. Characterization of antagonistic Bacillus methylotrophicus isolated from rhizosphere and its biocontrol effects on maize stalk rot. Phytopathology 2019, 109, 571-581. [CrossRef] [PubMed]

59. Bertrand, S.; Schumpp, O.; Bohni, N.; Bujard, A.; Azzollini, A.; Monod, M.; Gindro, K.; Wolfender, J.-L. Detection of metabolite induction in fungal co-cultures on solid media by high-throughput differential ultra-high pressure liquid chromatography-timeof-flight mass spectrometry fingerprinting. J. Chromatogr. A 2013, 1292, 219-228. [CrossRef]

60. Cawoy, H.; Debois, D.; Franzil, L.; De Pauw, E.; Thonart, P.; Ongena, M. Lipopeptides as main ingredients for inhibition of fungal phytopathogens by Bacillus subtilis/amyloliquefaciens. Microb. Biotechnol. 2015, 8, 281-295. [CrossRef]

61. Asari, S.; Ongena, M.; Debois, D.; De Pauw, E.; Chen, K.; Bejai, S.; Meijer, J. Insights into the molecular basis of biocontrol of Brassica pathogens by Bacillus amyloliquefaciens UCMB5113 lipopeptides. Ann. Bot. 2017, 120, 551-562. [CrossRef]

62. Calvo, H.; Marco, P.; Blanco, D.; Oria, R.; Venturini, M.E. Potential of new strain Bacillus amyloliquefaciens BUZ-14 as a biocontrol agent of postharvest fruit diseases. Food Microbiol. 2017, 63, 101-110. [CrossRef] [PubMed]

63. Townsend, G.K.; Heuberger, J.W. Methods for estimating losses caused by diseases in fungicide experiments. Plant Dis. Rep. 1943, 27, 340-343.

64. Bankevich, A.; Nurk, S.; Antipov, D.; Gurevich, A.A.; Dvorkin, M.; Kulikov, A.S.; Lesin, V.M.; Nikolenko, S.I.; Pham, S.; Prjibelski, A.D.; et al. SPAdes: A new genome assembly algorithm and its applications to single-cell sequencing. J. Comput. Biol. 2012, 19, 455-477. [CrossRef] [PubMed]

65. Carver, T.; Thomson, N.; Bleasby, A.; Berriman, M.; Parkhill, J. DNAPlotter: Circular and linear interactive genome visualization. Bioinformatics 2009, 25, 119-120. [CrossRef] [PubMed]

66. Darling, A.E.; Mau, B.; Perna, N.T. Progressive mauve: Multiple genome alignment with gene gain, loss and rearrangement. PLoS ONE 2010, 25, 5 .

67. Sullivan, M.J.; Petty, N.K.; Beatson, S.A. Easyfig: A genome comparison visualizer. Bioinformatics 2011, 27, 1009-1010. [CrossRef]

68. Meier-Kolthoff, J.P.; Auch, A.F.; Klenk, H.P.; Goker, M. Genome sequence-based species delimitation with confidence intervals and improved distance functions. BMC Bioinform. 2013, 14, 60. [CrossRef]

69. Yoon, S.H.; Ha, S.M.; Kwon, S.; Lim, J.; Kim, Y.; Seo, H.; Chun, J. Introducing EzBioCloud: A taxonomically united database of 16S rRNA and whole genome assemblies. Int. J. Syst. Evol. Microbiol. 2017, 67, 1613-1617. [CrossRef]

70. Kanehisa, M.; Sato, Y.; Morishima, K. BlastKOALA and GhostKOALA: KEGG tools for functional characterization of genome and metagenome sequences. J. Mol. Biol. 2016, 428, 726-731. [CrossRef]

71. Galperin, M.Y.; Wolf, Y.I.; Makarova, K.S.; Vera Alvarez, R.; Landsman, D.; Koonin, E.V. COG database update: Focus on microbial diversity, model organisms, and widespread pathogens. Nucleic Acids Res. 2021, 49, D274-D281. [CrossRef] [PubMed]

72. Lombard, V.; Golaconda Ramulu, H.; Drula, E.; Coutinho, P.M.; Henrissat, B. The carbohydrate-active enzymes database (CAZy) in 2013. Nucleic Acids Res 2014, 42, D490-D495. [CrossRef]

73. Kanehisa, M.; Sato, Y.; Kawashima, M.; Furumichi, M.; Tanabe, M. KEGG as a reference resource for gene and protein annotation. Nucleic Acids Res. 2016, 44, D457-D462. [CrossRef] 
74. Wu, S.; Zhu, Z.; Fu, L.; Niu, B.; Li, W. WebMGA: A customizable web server for fast metagenomic sequence analysis. BMC Genom. 2011, 12, 444. [CrossRef] [PubMed]

75. Zhang, H.; Yohe, T.; Huang, L.; Entwistle, S.; Wu, P.; Yang, Z.; Busk, P.K.; Xu, Y.; Yin, Y. dbCAN2: A meta server for automated carbohydrate-active enzyme annotation. Nucleic Acids Res. 2018, 46, W95-W101. [CrossRef]

76. Kanehisa, M.; Sato, Y. KEGG Mapper for inferring cellular functions from protein sequences. Protein Sci. 2020, $29,28-35$. [CrossRef] [PubMed]

77. Blin, K.; Shaw, S.; Steinke, K.; Villebro, R.; Ziemert, N.; Lee, S.Y.; Medema, M.H.; Weber, T. AntiSMASH 5.0: Updates to the secondary metabolite genome mining pipeline. Nucleic Acids Res. 2019, 47, W81-W87. [CrossRef] [PubMed] 